\title{
Energy from municipal solid wastes: Galati city case study
}

\author{
Bogdan Gabriel Carp ${ }^{1}$, Gabriel Mocanu ${ }^{1}$, Ion V. Ion ${ }^{1, *}$, and Florin Popescu ${ }^{1}$ \\ ${ }^{1}$ Thermal Systems and Automotive Department, "Dunarea de Jos" University of Galati, 800008 \\ Galati, 47 Domneasca St., Romania
}

\begin{abstract}
The municipal solid wastes (MSW) can be turned into resources through recycling and energy recovery. To obtain the maximum amount of energy, the appropriate technology must be applied to waste treatment. The composition and characteristics of municipal solid wastes are determinant for technologies choice for MSW in a city/region. Municipal authorities from the Galati city proposed a recovery rate of recyclable materials of $60 \%$ from MSW and treatment of the post-recycling MSW as follow: biodegradable fraction by anaerobic digestion and the combustible fraction by incineration or gasification. In this study traditional and innovative waste to energy technologies have been analysed and the potential of electrical energy of waste has been estimated. Results show that plasma gasification system of raw MSW coupled with gas turbine engine has almost the same electrical energy production (32.92 $\mathrm{GWh} /$ year) as conventional gasification of combustible material from MSW $(17.21 \mathrm{GWh} /$ year) coupled with anaerobic digestion of organic fraction of MSW (11.65 GWh/year). By recovering and using the landfill gas from the Tirighina landfill, $6.68 \mathrm{GWh}$ of electricity can be produced annually.
\end{abstract}

\section{Introduction}

With the development of human civilization, the problem of waste has become more and more complicated. Waste generation is primarily a loss of resources for the economy. The products from the moment they become waste are no longer intrinsic value, and they get negative value for the owner. If waste is disposed into nature, it is very difficult to recover resources embedded in it.

In 2018, the amount of generated municipal waste varied considerably from $766 \mathrm{~kg}$ per capita in Denmark to $272 \mathrm{~kg}$ per capita in Romania. The total amount of waste generated in the EU in 2018 was 250.474 million tonnes (489 $\mathrm{kg}$ of municipal waste per capita) from which $29 \%$ was recycled, $24 \%$ landfilled, $27 \%$ incinerated and $17 \%$ composted [1].

The authorities of EU member states' are obliged to establish waste management plans in accordance with the EU waste legislation and circular economy objectives [2]. The waste management system varies from one country to another, but it must be environmentally friendly, cost-efficient, accepted by the society, and has to meet the waste hierarchy (prevention, reuse, recycling, energy recovery and disposal). European Parliament set in 2017

\footnotetext{
* Corresponding author: ion.ion@ugal.ro
} 
new targets set by the European Parliament in 2017 for reuse and recycling of municipal solid waste at least $50 \%$ of total by 2025 and at least $60 \%$ by 2030 and for municipal solid waste landfill at maximum of $10 \%$ in 2035 [2, 3].

The large amount of waste generated at EU level and the high-energy content of waste (10 $\mathrm{MJ} / \mathrm{kg}$ ) indicate the importance of treating waste as a renewable energy source [4]. The European Commission in its communication COM/2017/0034 - The role of waste-to-energy in the circular economy, establishes the position of different waste-to-energy (WTE) processes in the waste hierarchy as follow: 1) anaerobic digestion of organic waste; 2) waste incineration and co-incineration with a high level of energy recovery and conversion of waste into liquid, gaseous or solid fuels; 3) waste incineration and co-incineration with a limited energy recovery and utilisation of collected landfill gas.

This paper reviews the most common WTE technologies (anaerobic digestion, incineration, gasification, and landfill gas recovery) in European Union and estimate the energy that can be recovered from MSW in order to provide technical information useful in the selection of the municipal solid waste treatment options.

\section{Waste-to-energy technologies}

The energy in the form of electricity and/or heat can be extracted from the MSW by thermal (combustion, pyrolysis, and gasification), biochemical (anaerobic digestion and fermentation) and chemical processes (esterification). Waste-to-energy technologies provide a clean means of energy recovery from the residual wastes while decreasing the volume of feedstock by about $90 \%$. Residual waste represents the waste remaining after removing any recyclable component from MSW and is the primary fuel for the WTE plants.

The energy recovery from residual wastes depends on the chosen pathway and certain physical (size of constituents, density, inert and moisture content) and chemical (volatile solids, fixed carbon content, energy content, carbon/nitrogen ratio, elemental composition, toxicity of waste) characteristics. The residual wastes as a fuel have specific characteristics (poor-quality fuel, low energy content, variable composition, and high contents of pollutants) which determine the design of waste to energy plants and the need to tailor a flexible and reliable technical solution [5].

There is no best WTE technology as this is extremely site-specific, depending on local circumstances (desired outputs, tipping fees, waste quantities and characteristics, environmental regulations, by-product management practices) and many other factors [6].

There are a number of different WTE technologies, which are not in competition with each other, with some providing one or more energy form, and others involving pre-treatment processes to prepare the waste feedstock for energy recovery. As the MSW is a heterogeneous feedstock, pre-treatment process is required in order to convert MSW in a fuel (refuse derived fuel - RDF) with improved handling characteristics and homogeneity. The pre-treatment process includes: shredding, screening, sorting, drying and pelletisation.

Figure 1 shows the simplified process schematic for four types of commercially proven in full-scale plant treatment technologies discussed in this paper: incineration, gasification, anaerobic digestion and landfill gas recovery.

Most running WTE plants produce electricity only, though the efficiency is considerably lower than for plants that supply heat or both electricity and heat, because: electricity is more valuable than heat; electricity can simply be exported to the local grid and heat generation requires consumer in close proximity [7].

The global net electrical efficiency of a WTE system is equal to the ratio between the net electrical energy produced $\left(E_{e l}\right)$ and the input thermal energy of the MSW referred to its Lower Heating Value ( $L H V)$ : 


$$
\eta_{e l}=\frac{E_{e l}}{m_{M S W} \cdot L H V_{M S W}}
$$

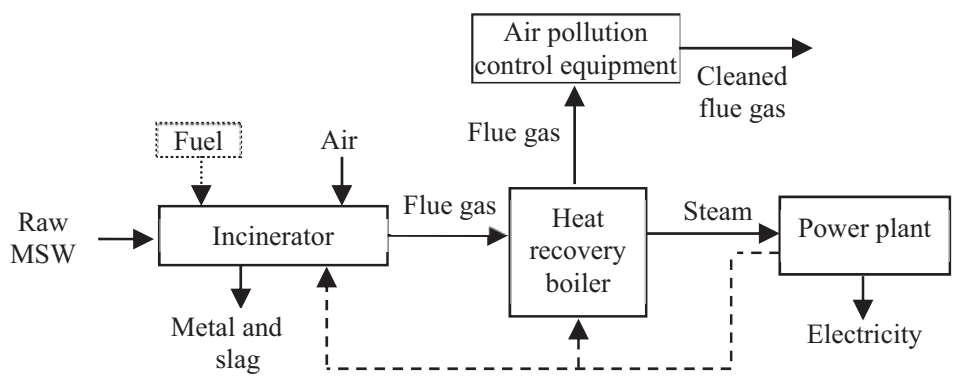

a). Flow chart of waste to energy incinerator

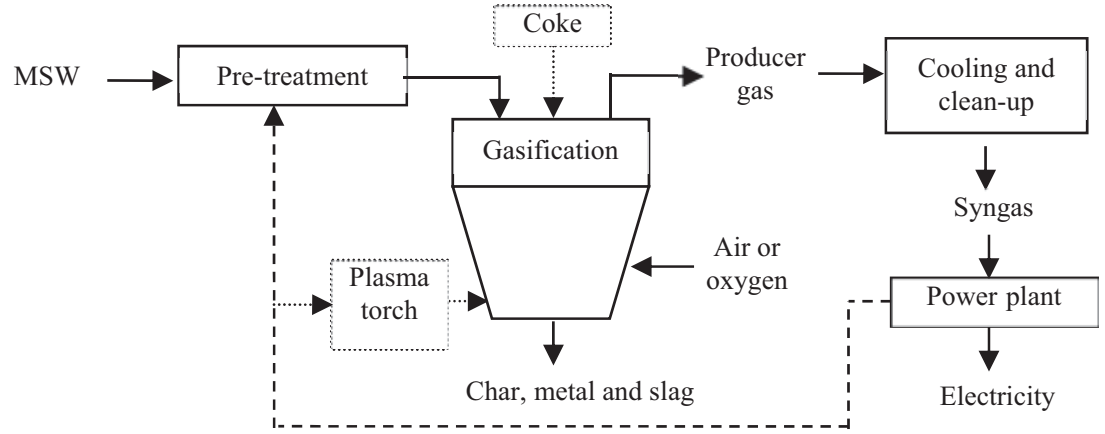

b). Flow chart of waste to energy via gasification

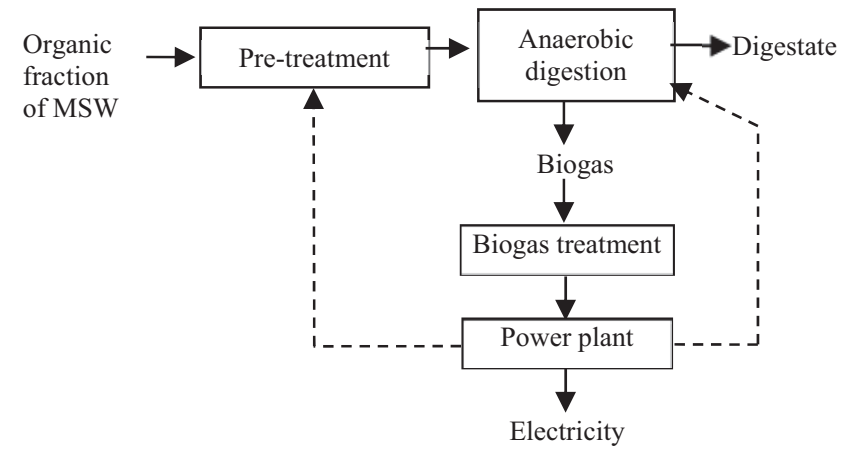

c). Flow chart of waste to energy via anaerobic digestion

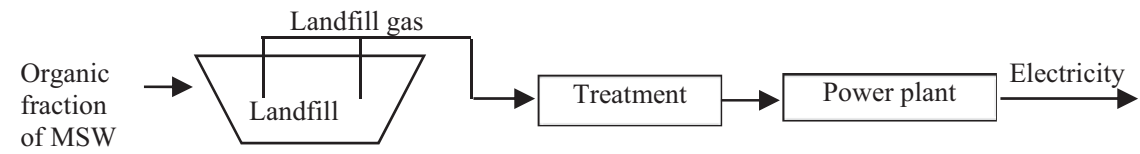

d). Flow chart of landfill gas to energy

Fig. 1. Schematic representation of incineration, gasification, anaerobic digestion and landfill gas based waste to energy plants. 


\subsection{MSW Incineration}

Incineration is the most mature and widely used WTE technology. Japan is followed by the European Union and United States in terms of quantity of waste incinerated. About $50 \%$ of the total quantity of MSW generated in Germany and Sweden are incinerated, about $65 \%$ in Denmark and $80 \%$ in Switzerland [5].

A way to assess the fuel quality of a waste is to determine the water content, the ash content and the combustible matter content. The MSW can be burnt without auxiliary fuel when: its water content is below $50 \%$ and ash content is below $60 \%$ and carbon content is above $25 \%$ [5].

The European Union imposed strict operating conditions on waste incineration plants to prevent air pollution such as a temperature inside the combustion chamber of at least $850^{\circ} \mathrm{C}$ for non-hazardous waste and $1100^{\circ} \mathrm{C}$ for hazardous waste for at least two seconds for the flue gas. To achieve this each incineration plant shall be equipped with at least one auxiliary burner (Directive 2000/76/EC of the European Parliament and of the Council of 4 December 2000 on the waste incineration).

The wastes are combusted, and the heat is recovered in a boiler to generate steam that drives turbine which powers a generator to produce electricity. The modern incineration plants are able to combust MSW to highest standard by using advanced combustion and emission control technologies. Incinerators can be built both on a small scale and a large scale. The most commonly used combustion process is mass-burn combustion, able to combust "as-received" MSW, mixed wastes or post recycling MSW without any additional pre-treatment, and RDF combustion. The main incineration furnace types include: moving grate for mixed municipal waste and fluidized beds for sorted wastes (RDF). Their size varies significantly across the world. The mass burning offers great flexibility for the type of feedstock, and the RDF combustion allow removing of recyclables and contaminants from the feedstock, but with the increase in operating costs instead.

The net electrical efficiency of incineration plants varies from $15 \%$ to $25 \%$ depending on the size of plant. This efficiency (which takes into account the energy consumed in the incineration process itself) is low compared to fossil fuel plant because of the lower calorific value of the MSW and limitations on steam temperatures to avoid corrosion caused by acid gases produced by combustion of MSW. The electrical efficiency can be increased up to $30 \%$ (electricity only) by using more advanced energy recovery techniques such as integration of WTE plant with Combined Cycle Gas Turbine [7].

The electricity that can be generated by an incineration plant can be estimated by using equation (1), namely by multiplying the net electrical efficiency of WTE plant by energy content of incinerated waste (i.e lower heating value - LHV) (Tab. 1).

Table 1. Ultimate analysis and LHV of MSW streams [8-10].

\begin{tabular}{|c|c|c|c|c|c|c|}
\hline \multirow{2}{*}{ Category } & \multicolumn{5}{|c|}{ Ultimate analysis (\% mass) } & \multirow{2}{*}{$\begin{array}{c}\text { LHV } \\
(\mathrm{kJ} / \mathrm{kg})\end{array}$} \\
\cline { 2 - 6 } & $\mathbf{C}$ & $\mathbf{H}$ & $\mathbf{O}$ & $\mathbf{N}$ & $\mathbf{A s h}$ & \\
\hline Paper & 43.41 & 5.82 & 44.32 & 0.25 & 6.00 & 10840 \\
\hline Plastics & 60.00 & 7.20 & 22.80 & 0 & 10.00 & 25630 \\
\hline Textiles & 55.00 & 6.60 & 31.20 & 4.60 & 2.40 & 15900 \\
\hline Wood & 49.40 & 6.10 & 43.70 & 0.10 & 0.60 & 13940 \\
\hline Food wastes & 44.99 & 6.43 & 28.76 & 3.30 & 16.00 & 5420 \\
\hline Yard wastes & 40.31 & 5.64 & 39.00 & 2.00 & 13.00 & 2810 \\
\hline * ${ }_{\text {wet basis }}$
\end{tabular}




\subsection{MSW Gasification}

MSW can be converted into a gaseous fuel (producer gas) and a solid product (containing char and ashes) through gasification which is a partial oxidation of the MSW in the presence of an oxidant (air, oxygen) under substoichiometric combustion conditions. Gasification can be carried out also by using heat from an external source and steam as gasification agent, and by using plasma arc torches and air, oxygen or steam as gasification agent. The MSW gasification is a complex process that takes place at temperatures above $600^{\circ} \mathrm{C}$ and includes a large number of reactions. In plasma gasification the arc torches produce a very high temperature plasma gas which allows feedstock of variable particle size, composition, with minimal feed preparation $[11,12]$.

The producer gas containing partially oxidized products (carbon monoxide, hydrogen, methane) and undesired products (particulate, tar, alkali metals, chloride and sulphide) can be used directly in a steam boiler or after its cleaning in an internal combustion engine, gas turbine or fuel cell to generate electricity.

There are many types of gasification reactors: fixed bed, fluidized bed, entrained bed, vertical shaft, moving grate furnace, rotary kiln and plasma reactor. Almost all gasification reactors use pre-treated wastes in order to increase the heating value of the feedstock and to avoid gasifier operational problems. The pre-treatment usually includes size reduction, screening and separation to remove the non-combustible materials from the MSW and is carried out with additional energy consumption. Because the waste pre-treatment increases the cost of gasification, this process is more appropriate in communities with recycling programs [13].

Almost all types of gasification reactors are designed to operate with a certain type of waste (RDF, mixed plastic waste, packaging derived fuel, paper industry waste, sewage sludge, automotive shredder residue), but co-gasification (MSW and coke) and plasma gasification can be used with mixed wastes $[13,14]$.

The energy content (LHV) of producer gas depends greatly on the gasification medium: the LHV varies from (4-7) $\mathrm{MJ} / \mathrm{Nm}^{3}$ when air is used, from (10-15) $\mathrm{MJ} / \mathrm{Nm}^{3}$ when oxygen is used and from (15-20) $\mathrm{MJ} / \mathrm{Nm}^{3}$ when steam is used as gasification medium [11].

In plasma gasification process, due to the extreme temperatures $\left(2000-7000^{\circ} \mathrm{C}\right)$, almost the entire carbon contained in waste is converted into $\mathrm{CO}$, all hazardous substances are neutralised, inorganic matter is vitrified into inert slag and the produced gas has higher calorific value, making possible its use in gas turbines or internal combustion engines to generate electricity [13].

Gasification has some important advantages over incineration: fuel gas generated by gasification is easier to handle, control and burn than solid MSW; gasification plants can be designed for a small-medium scale, has higher energy efficiency when producer gas cleaning is not required and generates less pollutant [12].

Gasification process is influenced by many parameters and it is desirable to find their adequate combination to obtain an efficient treatment of different kind of wastes. The performance of a gasification process is described mainly by the producer gas heating value, $\left(\mathrm{kJ} / \mathrm{Nm}^{3}\right)$, specific producer gas flow rate $\left(\mathrm{Nm}^{3} / \mathrm{kg}\right.$ waste) and the cold gas efficiency (CGE) defined as follow:

$$
C G E=\frac{\dot{V}_{\text {prod,gas }} \cdot L H V_{\text {prod,gas }}}{\dot{m}_{\text {feedstock }} \cdot L H V_{\text {feedstock }}+W_{\text {torch }}}
$$

where: $\dot{V}_{\text {prod,gas }}$ and $\dot{m}_{\text {feedstock }}$ are volumetric flow rate of producer gas, $\mathrm{Nm}^{3} / \mathrm{s}$ and mass flow rate of feedstock respectively, $\mathrm{kg} / \mathrm{s} ; L H V_{\text {prod,gas }}$ and $L H V_{\text {feedstock }}$ are lower heating value of 
producer gas, $\mathrm{kJ} / \mathrm{Nm}^{3}$ and of feedstock respectively, $\mathrm{kJ} / \mathrm{kg} ; W_{\text {torch }}$ is power required to produce thermal plasma, $\mathrm{kW}$.

Plasma gasification plants require an internal power consumption of about (1200 $2500) \mathrm{MJ} / \mathrm{t}_{\text {waste }}$ to operate the plasma torch, which means $(5-10) \%$ of the energy of the feed waste and a consumption of (15-20)\% of the gross power output of the plant [12].

The cold gas efficiency depends mainly on the composition of the feedstock and gasification temperature. Each MSW stream has a temperature range at which it is extracted the maximum amount of energy by gasification (CGE is maximum) (Fig. 2).

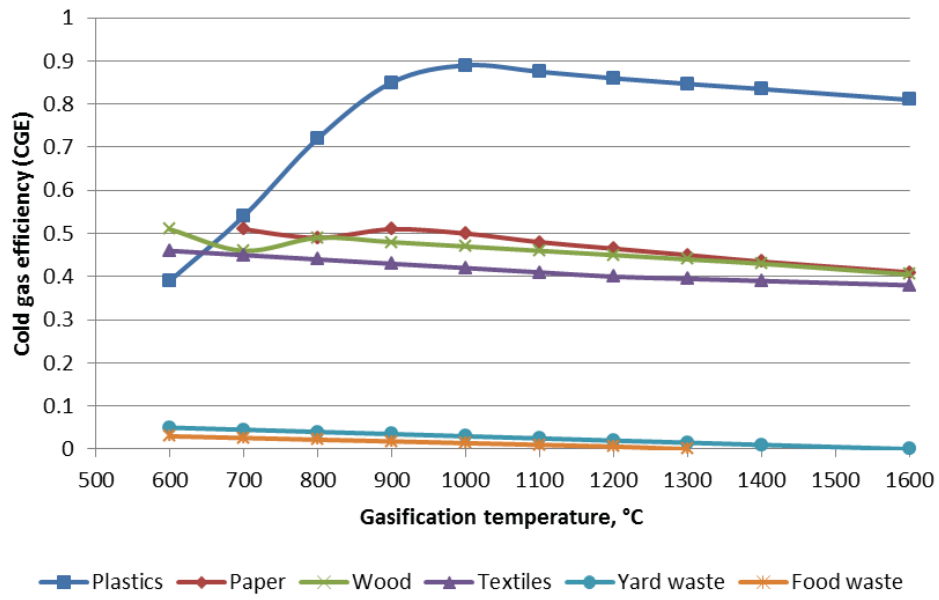

Fig. 2. Cold gas efficiency (CGE) of the six gasifiable streams in MSW [8].

The composition of producer gas can be predicted by using the following software programs: Aspen Plus, ChemCAD, Computational Fluid Dynamics, MatLab, UniSim, CyclePad, Gasify_2.01, Barracuda Virtual Reactor etc. The heating value of the gasification products can be calculated once their composition is determined.

The gasification-based WTE technologies can operate independently or in combination with other waste treatment technologies (pyrolysis, incineration).

The producer gas can be used in different heat engines for power generation. It can be first cleaned (to remove contaminants such as particulate, tar, alkali metals, chloride and sulphide) and then burnt or can be first burnt and then cleaned (flue gas cleaning) depending on the requirements of the heat engines.

The most used heat engine in the WTE gasification-based plants in operation today is the Rankine steam engine because no limitations are imposed on the content of contaminants [11].

The net efficiency of gasification plants varies from 15 to $25 \%$ when using a steam turbine, from 20 to $30 \%$ when using a gas turbine and from 14 to $26 \%$ when using an internal combustion engine $[12,15]$.

\subsection{MSW anaerobic digestion}

The anaerobic digestion (AD) is applied to organic fraction of MSW to obtain biogas (methane $50-70 \%$, carbon dioxide $30-40 \%$, nitrogen $<5 \%$, hydrogen sulphide, siloxanes, ammonia) and digestate in the absence of oxygen (Fig. 1.d). The AD process has economic and environmental benefits and it is considered the best option for the biological production of methane. In Europe exists around 1000 plants with around 500 in Germany and 140 in UK and Italy [16]. 
Organic fraction of MSW is a suitable substrate for anaerobic digestion due to high moisture and volatile solids content. Anaerobic digestion is a complex microbial process which involves four different stages and each stage has different process parameters requirement $(\mathrm{pH}$, particle size, carbon to nitrogen ratio, temperature, total solids content, total volatile solids content and the inoculum type). The process efficiency can be improved by controlling several operational and technology specific parameter such as: quality of waste separation and pre-treatment; mesophilic or thermophilic temperature conditions; wet or dry fermentation; batch or continuous reactor; single stage or two-stage digestion; type of codigestion substrate (animal manure or other types of waste) [17]. Mesophilic digestion is preferred because it requires less heating and because it is more stable process.

The theoretical biogas yield from anaerobic digestion of different waste categories can be calculated by using the Buswell stoichiometric equation:

$$
\begin{gathered}
C_{c} H_{h} O_{o} N_{n} S_{s}+\frac{4 c-h-2 o+3 n+2 s}{4} H_{2} \mathrm{O} \rightarrow \frac{4 c+h-2 o-3 n-2 s}{8} C_{4}+ \\
+\frac{4 c-h+2 o+3 n+2 s}{8} \mathrm{CO}_{2}+n \mathrm{NH}_{3}+\mathrm{SH}_{2} \mathrm{~S}
\end{gathered}
$$

where the term $C_{c} H_{h} O_{o} N_{n} S_{s}$ represents the chemical formula of the waste matter at the begining of decomposition.

To estimate the production and composition of the biogas, different software (AspenPlus, Simba\#Biogas, AD4RD tool, BioWin, SuperPro Designer, proSimPlus, CFD software ANSYS Fluent, AQUASIM, Biogas World, CRAN - Package biogas etc) are used or data based on modelling assumption and published biogas yields from digesters treating a variety of wet MSW types (Tab. 2).

Table 2. Biogas yields from the anaerobic digestion of organic fraction of MSW [18].

\begin{tabular}{|c|c|}
\hline Organisation/Institute & Biogas generation rate \\
\hline Global Methane Initiative & "Rule of thumb" for biogas production rate $=100 \mathrm{~m}^{3}$ \\
biogas per Mg MSW
\end{tabular}

Biogas can be used in internal combustion engines, boilers with steam turbine, gas turbines and fuel cells or can be converted into biomethane to be used as transport fuel or injected in the natural gas network. Today, in almost all AD facilities the biogas is burned in an internal combustion engine to generate electricity. The small-scale internal combustion engines with a capacity below $200 \mathrm{~kW}$ have an electrical conversion efficiency up to $25 \%$ and larger internal combustion engines (up to $1.5 \mathrm{MW}$ ) have an electrical conversion efficiency of (30-35)\% [19].

\subsection{Landfill gas}

The landfill has the highest environmental impact amongst all waste management options. Once MSW has been deposited in a sanitary landfill, bacteria break down under anaerobic conditions the organic material producing landfill gas and leachate. Typically, landfill gas 
contains $(45-60) \%$ methane, $(40-60) \%$ carbon dioxide, $(0-1.0) \%$ hydrogen sulphide, $(0-$ $0.2) \%$ hydrogen and water vapour. The composition of generated landfill gas varies significantly on composition of the waste and operating conditions at the landfill.

The process of landfill gas formation follows a well-defined kinetic pattern in which the gas formation begins about 6 months after the waste is deposited and reaches a maximum at about 20 years, then decreases over the course of several decades. Landfill gas is extracted by the aide of a blower through the installation of wells installed in the waste mass and sent to the treatment unit (Fig. 1.d). The efficiency of landfill gas collection system is about $84 \%$ of produced gas [20].

The landfill gas production from the existing landfills can be evaluated by using various models, such as the 2006 IPCC, TNO, GasSim, Afvalzorg, EPER France, LandGEM (USEPA) and others [21]. The U.S. Environmental Protection Agency along with Clean Air Technology Center developed an automated estimation tool (Landfill Gas Emissions Model - LandGEM) to estimate emission rates for total landfill gas, methane, carbon dioxide and other gases from municipal solid waste landfills [22]. LandGEM applies the following firstorder exponential equation:

$$
Q_{C H_{4}}=\sum_{i=1}^{n} \sum_{j=0.1}^{10} k \cdot L_{0} \frac{M_{i}}{10} e^{-k \cdot t_{i, j}}
$$

where: $Q_{C H 4}$ - annual methane generation in the year of the calculation ( $\mathrm{m}^{3} /$ year); $i=1$ - year time increment; $n=$ (year of the calculation) - (initial year of waste acceptance); $j=0.1$ year time increment; $k$ - methane generation rate (1/year) ( $k$ values for arid and conventional landfills is limited to 0.02 for sites that experience less than $635 \mathrm{~mm}$ of precipitation per year and 0.04 or 0.05 for sites that experience higher rainfall amounts); $L_{0}$ - potential methane generation capacity $\left(\mathrm{m}^{3} / \mathrm{Mg}\right)\left(L_{0}=100-170 \mathrm{~m}^{3} / \mathrm{Mg}\right.$ waste $) ; M_{i}$ - mass of waste disposed in the $i^{\text {th }}$ year $(\mathrm{Mg}) ; t_{i j}$ - age of the $j^{\text {th }}$ section of waste mass $M_{i}$ disposed in the $i^{\text {th }}$ year (decimal years)

Energy recovery from landfill gas can be achieved through direct combustion in furnaces; conversion into bio-diesel or methanol and electricity generation. The employed technologies for electricity generation are as follow: internal combustion engines; gas turbines; organic Rankine cycle; Stirling engines and fuel cells. The efficiency, consumption and emissions of these technologies are given in Table 3.

Table 3. Characteristics of engines operating on landfill gas [23].

\begin{tabular}{|c|c|c|c|c|c|}
\hline \multirow{2}{*}{ Characteristics } & \multicolumn{5}{|c|}{ Landfill gas power plant } \\
\cline { 2 - 6 } & $\begin{array}{c}\text { Internal } \\
\text { combustion } \\
\text { engine }\end{array}$ & $\begin{array}{c}\text { Gas } \\
\text { turbine }\end{array}$ & $\begin{array}{c}\text { Organic } \\
\text { Rankine } \\
\text { cycle }\end{array}$ & $\begin{array}{c}\text { Stirling } \\
\text { engine }\end{array}$ & $\begin{array}{c}\text { Molten } \\
\text { carbonate } \\
\text { fuel cell }\end{array}$ \\
\hline $\begin{array}{c}\text { Electric efficiency } \\
(\%)\end{array}$ & 33 & 28 & 18 & 38.5 & 50 \\
\hline $\begin{array}{c}\text { Fuel consumption } \\
(\mathrm{kJ} / \mathrm{kWh})\end{array}$ & 10972 & 12872 & 19202 & 9390 & 7174 \\
\hline $\begin{array}{c}\mathrm{NO} \text { ( emission } \\
(\mu \mathrm{g} / \mathrm{kJ})\end{array}$ & 56.6 & 15 & 16 & 3.11 & - \\
\hline $\begin{array}{c}\mathrm{CO} \mathrm{emission} \\
(\mu \mathrm{g} / \mathrm{kJ})\end{array}$ & 56.6 & 19 & 18.9 & 15 & 1.4 \\
\hline
\end{tabular}

In addition to the technical and energy analysis, when choosing the MSW treatment option, another equally important criterion is that related to capital costs and operating and maintenance costs. As these costs include several components (cost of land acquisition, raw material and equipment procurement, cost of planning, contractual support, technical and financial services, etc.) they vary from one region to another, from one country to another. The capital cost of a WTE plant depends on the quantity and quality of waste as feedstock 
and the technology employed. The estimated cost of different WTE technologies are presented in Table 4. The capital costs mentioned in Table 4 include the cost for the acquisition of both the MSW treatment plant and the electricity generation unit. A large part of these costs will be recovered by selling the generated electricity.

Table 4. Costs of WTE technologies [24].

\begin{tabular}{|c|c|c|}
\hline WTE Technology & $\begin{array}{c}\text { Capital cost } \\
\text { (USD/t/year) }\end{array}$ & $\begin{array}{c}\text { Operational cost } \\
\text { (USD/t/year) }\end{array}$ \\
\hline Incineration & $400-700$ & $40-70$ \\
\hline Conventional gasification & $250-850$ & $45-85$ \\
\hline Plasma arc gasification & 600 & 90 \\
\hline Anaerobic digestion & $50-350$ & $5-35$ \\
\hline Landfilling with gas recovery & $10-30$ & $1-3$ \\
\hline
\end{tabular}

\section{Municipal solid wastes from the Galati city}

According to the Master Plan for the Integrated Project Management System in Galati County issued in 2019, about $93 \%$ of the total MSW collected in 2017 was deposited and the difference represented by recyclable waste and biowaste from parks and gardens was collected separately and capitalized. In recent years, there has been a slightly decreasing trend in the quantities of municipal waste generated (the average generation rate is 0.82 $\mathrm{kg} / \mathrm{capita} /$ day, in the Municipality of Galaţi), and the structure of MSW has remained relatively constant. The landfill Tirighina has an area of 14.4 ha and a total volume of $2120000 \mathrm{~m}^{3}$. It was opened in 2011 and will be closed by the end of 2023 . The average composition of the wastes is given in Table 5 . The average total waste generation rate was $100557.28 \mathrm{t}$ /year. The municipality of Galati proposed to increase the recycling rate to $60 \%$ till 2021, and to use waste treatment alternatives, other than landfills, in order to decrease environmental pollution and socio-economic impacts. The following MSW treatment options were analysed: 1) anaerobic digestion of the organic fraction and incineration of residual MSW; 2) anaerobic digestion of the organic fraction and conventional gasification of residual MSW, and 3) plasma gasification of the entire MSW stream.

Table 5. Composition of MSW from the Galaţi city.

\begin{tabular}{|c|c|}
\hline Component & $\begin{array}{c}\text { Participation } \\
(\% \text { mas })\end{array}$ \\
\hline Food waste & 47.40 \\
\hline Plastics & 9.40 \\
\hline Paper waste & 15.80 \\
\hline Wood & 3.00 \\
\hline Textile & 2.50 \\
\hline Yard & 7.30 \\
\hline Metal & 2.50 \\
\hline Glass & 2.90 \\
\hline Others & 9.20 \\
\hline
\end{tabular}

This study aims at estimating the total potential of energy that can be obtained from the municipal solid waste in each treatment option mentioned above. In addition to obtaining 
energy from freshly generated MSW, energy that can be recovered by collecting landfill gas from the sanitary landfill Tirighina is also considered.

For the incineration of residual MSW was considered the mass-burn furnace combined with steam turbine engine with a net electrical efficiency of $25 \%$.

For the anaerobic digestion of organic fraction was considered continuous, high solids, single-stage, stirred tank reactor with a biogas production rate of $100 \mathrm{~m}^{3}$ biogas per tonne MSW and a methane content in biogas of $60 \%$. The biogas is used in an internal combustion engine to generate electricity with the net electrical efficiency of $33 \%$

Gasification of MSW was considered coupled with gas turbine engine with the net electrical efficiency of $30 \%$. Plasma gasification was considered to have the electricity consumption for torch arc of $1900 \mathrm{MJ} / \mathrm{t}_{\text {waste }}$.

The energy output from the landfill gas was calculated by using the LandGEM (Landfill Gas Emissions Model) tool version 3.02 for landfill gas production and considering internal combustion engine for power generation. The input data for the LandGEM tool are: the landfill open and closure years; waste acceptance rates (100557.28 t/year); methane generation rate $\left(k=0.04\right.$ year $\left.^{-1}\right)$; potential methane generation capacity $\left(L_{0}=100 \mathrm{~m}^{3} / \mathrm{Mg}\right)$; methane content $(50 \%)$ and the model waste acceptance limit (80 years).

The landfill gas and methane generation over the 80 years since the landfill opened are shown in Figure 3. The surface area below the curves represents the total amount of generated landfill gas and $\mathrm{CH}_{4}$ respectively. The average lower heating value of landfill gas was considered $17000 \mathrm{~kJ} / \mathrm{Nm}^{3}$, the efficiency of landfill gas collection $84 \%$ and the electric efficiency of internal combustion engine used to generate electricity $33 \%$. Because the amount of generated landfill gas varies from year to year the average amount of landfill gas generated annually in the period 2020-2050 was calculated (30 years is the expected lifetime of a power plant).

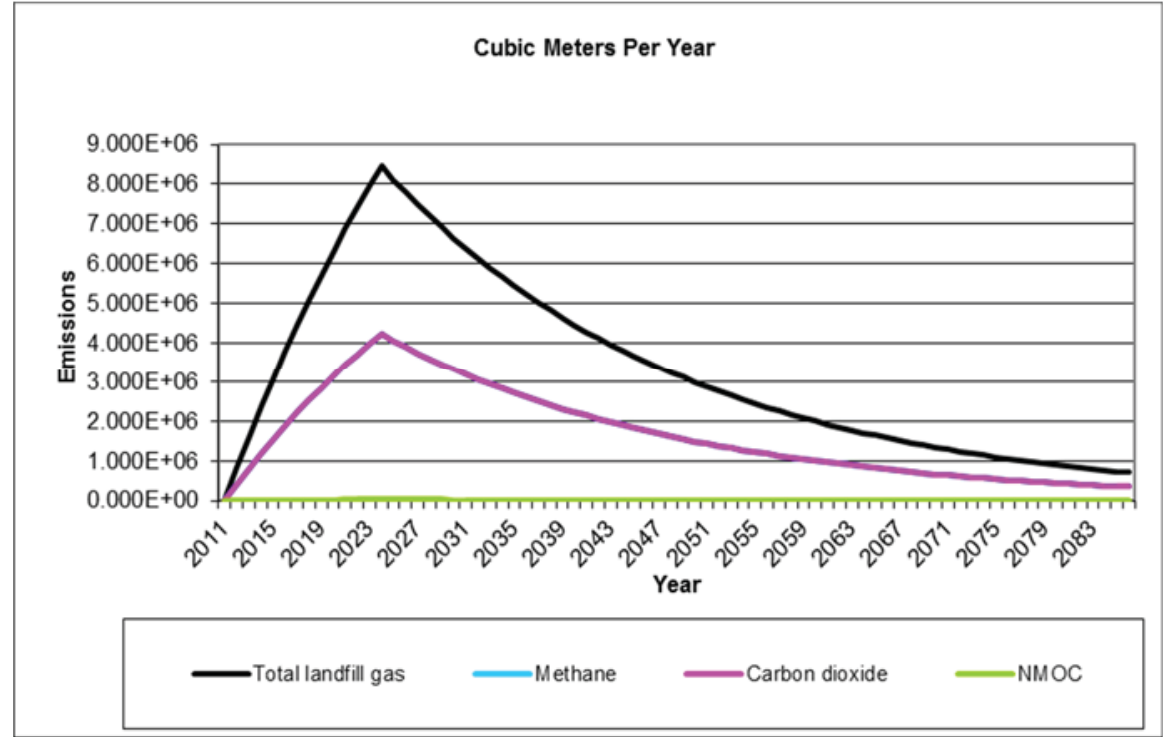

Fig. 3. Total landfill gas and methane generations (methane content $50 \%$ by volume).

By anaerobic digestion of the MSW organic fraction, $5500000 \mathrm{~m}^{3}$ of biogas can be obtained annually. From the Tirighina landfill can be collected on the average $4289250 \mathrm{~m}^{3}$ of landfill gas.

The potential amount of electricity that can be generated in each option of MSW treatment is shown in Figure 4. It can be noticed that the largest yearly amount of electrical energy can 
be obtained through plasma gasification coupled with gas turbine $(32.92 \mathrm{GWh})$, which is almost the same electrical energy production as conventional gasification of combustible material from MSW (17.21 GWh/year) coupled with anaerobic digestion of organic fraction of MSW (11.65 GWh/year).

MSW incineration can generate less electricity than gasification, but it has the advantage that it can be applied to waste without pre-treatment, thus reducing costs.

The electrical energy generated from landfill gas in an internal combustion engine can reach $6.68 \mathrm{GWh} /$ year.

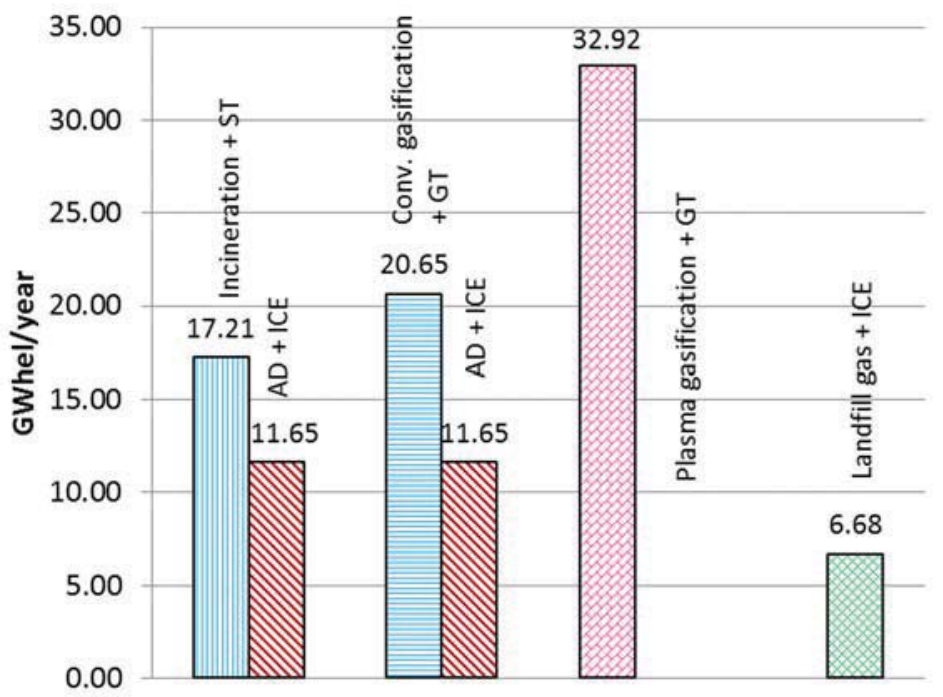

Fig. 4. Amount of electrical energy that can be generated from the MSW in Galati City.

Although plasma gasification requires internal energy consumption for plasma torch, it is preferable because it can be applied to the waste mixture, unsorted raw waste.

The generated electrical energy can supply about 11000 homes (with average consumption of $300 \mathrm{kWh} / \mathrm{month} /$ household), which represents a tenth of total number of housing in the city of Galati. By selling the electrical energy with $0.1421 € / \mathrm{kWh}$, a sum of $5600000 €$ can be obtained and used to cover the operation and maintenance costs and a part of the investment cost of the WTE plant.

\section{Conclusions}

MSW represents only about $10 \%$ of total generated wastes but it raises many problems due to its varied composition and characteristics, its distribution among many sources and its dependence on the consumer behaviour.

Each person in Europe is currently producing annually about $500 \mathrm{~kg}$ of household waste, from which only $40 \%$ of it is reused or recycled. The main objective of European legislation is turning waste into a resource through recycling, limiting the use of landfilling and changing the consumer behaviour. To achieve this goal, all EU member states need to improve their waste management system.

The common waste-to-energy technologies are reviewed and the electrical energy production from MSW in the Galati city is estimated. Three options of MSW treatment have been analysed: AD of organic fraction combined with incineration of residual MSW; AD of organic fraction combined with conventional gasification of residual MSW and plasma 
gasification of the entire stream of MSW. Plasma gasification applied to the entire amount of MSW produces the largest amount of electrical energy (32.92 GWh/year). AD applied to organic fraction of MSW generates $11.65 \mathrm{GWh} /$ year. Conventional gasification can generate 17.21 GWh/year and incineration 20.65 GWh/year. By recovering the landfill gas and its use in an internal combustion engine can be produced $6.68 \mathrm{GWh} /$ year. The generated electrical energy can supply about a tenth of total number of housing in the city of Galati.

The estimation results can be used by the municipal authority for the evaluation of proposed technologies for MSW treatment in terms of energy recovery.

\section{References}

1. Eurostat. Municipal waste statistics. (https://ec.europa.eu/eurostat/statisticsexplained/index.php/Municipal_waste_statistics\#Municipal_waste_treatment) (Accessed: 20 June 2020)

2. J. Malinauskaite, H. Jouhara, D. Czajczynska, et al. Energy 141 (2017)

3. European Parliament. Amendments adopted by the European parliament on 14 March 2017 on the proposal for a directive of the European parliament and of the council amending directive 2008/98/EC on waste (COM(2015)0595 e C8-0382/2015 e 2015/0275(COD)). Strasbourg (2017)

4. A. Porteous, Waste Manag. 25(4) (2005)

5. C. Cord'homme, Alternative Thermal Treatment for Municipal Solid Waste-to-Energy plants, ISWA Congress, Novi Sad, 19-21 September (2016)

6. L. Yassin, P. Lettieri, S.J.R. Simons, Chem. Eng. J. 146 (2009)

7. K. Whiting, S. Wood, M. Fanning, Waste technologies: waste to energy facilities (WSP Environmental Ltd, London, 2013)

8. H. A. Arafat, K. Jijakli, Waste Manag. 33 (2013)

9. S. Consonni, F. Viganò, Waste Manag. 31 (2011)

10. I. Iliev, N. Kaloyanov, P. Gramatikov, A. Terziev, I. Palov, S. Stefanov, K. Siracov, V. Kamburova, Energy Efficiency and Energy Management Handbook (University of Ruse "Angel Kanchev", 2012)

11. L. Lombardi, E. Carnevale, A. Corti, Waste Manag. 37 (2015)

12. U. Arena, Waste Manag. 32 (2012)

13. National Energy Technology Laboratory (https://netl.doe.gov/research/coal/energysystems/gasification/gasifipedia/waste) (Accessed: 30 May 2020)

14. N. Tanigaki, Energy from Waste. Waste Gasification and Melting Technology - Direct Melting System, Steinmüller Babcock Environment GmbH (www.eng.nipponsteel.com) (Accessed: 20 May 2020)

15. R. Jingzheng, Waste-to-Energy. Multi-Criteria Decision Analysis for Sustainability Assessment and Ranking (Academic Press 2020)

16. S. Panigrahi, B. K. Dubey, Renewable Energy 143 (2019)

17. A. Kumar, S.R. Samadder, Energy 197 (2020)

18. T. Frankiewicz, Summary of Findings Anaerobic Digestion for MSW, Global Methane Initiative Agriculture, Municipal Solid Waste and Municipal Wastewater Best Practices Workshop and Subcommittee Meetings, Florianopolis, Brazil, 14 March (2014)

19. P. Wheeler, Biogas and More! System and Markets Overview of Anaerobic Digestion (AEA Technology Environment, UK, 2001) 
20. J. Speight, Natural Gas: A Basic Handbook (Gulf Professional Publishing, 2018)

21. M. Temirbekova, M. Aliyarova, I. Iliev, Al. Yelemanova1, S. Sagintayeva1, E3S Web Conf. 180, 02019 (2020)

22. https://www3.epa.gov/ttncatc1/dir1/landgem-v302-guide.pdf (Accessed: 15 March 2020)

23. R. Bove, P. Lunghi, Energy Convers. Manag. 47 (2006)

24. K. Atul, S.R. Samadder, Waste Manag. 69 (2017) 